dr inż. Marek Sobaś

Instytut Pojazdów Szynowych „, TABOR”

\title{
Wózek 11ANc dla wagonu osobowego przeznaczonego do wysokich prędkości
}

\begin{abstract}
$W$ artykule przedstawiono koncepcję nowego wózka 11ANc, przeznaczonego do prędkości 250 $\mathrm{km} / \mathrm{h}$, z możliwościq modyfikacji do $300 \mathrm{~km} / \mathrm{h}$. Wózek ten powstat na bazie wózka 11ANa, zabudowanego pod wagonem 150 A, przeznaczonym do prędkości $200 \mathrm{~km} / \mathrm{h}$. Taki rozwój pozwala na wykorzystanie i dostosowanie obecnego pudła wagonu 150 A do zabudowy wózka nowej generacji. Zaprezentowano podstawowe parametry wózka i omówiono podstawowe grupy konstrukcyjne. Artykut powstal w ramach projektu badawczo-rozwojowego $\mathrm{nr}$ R10 041 02, finansowanego przez Ministerstwo Nauki i Szkolnictwa Wyższego ze środków budżetowych na naukę na lata

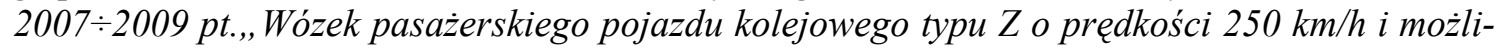
wości modyfikacji do prędkości $300 \mathrm{~km} / \mathrm{h}$ ”.
\end{abstract}

\section{Wstęp}

Wózki toczne dla wagonów osobowych, przystosowane do wysokich prędkości powyżej $250 \mathrm{~km} / \mathrm{h}$ muszą spełniać szereg wymagań przepisów międzynarodowych, zawartych w kartach UIC, normach europejskich EN, opracowanych przez Europejski Komitet Normalizacyjny (fr. „Comité Européen de Normalisation") oraz wymagania przepisów ruchu międzynarodowego, sformułowane w RIC [18]. Jak wykazano w $[1 \div 4]$ główne problemy związane $\mathrm{z}$ dostosowaniem układu biegowego do wysokich prędkości związane są z zachowaniem własności dynamicznych pojazdu jako całości. $\mathrm{Z}$ analiz przedstawionych $\mathrm{w}[1 \div 3]$ wynika, że zagadnienia te można rozwiązać przez zastosowanie zabiegów konstrukcyjnych w samym wózku ale również $\mathrm{w}$ infrastrukturze kolejowej, która musi spełniać bardzo ostre kryteria w zakresie geometrii toru ( prześwit i dopuszczalne tolerancje) i w warunkach krajowych musi być również poważnie doinwestowana. Jak wynika $\mathrm{z}$ analizy drgań strukturalnych pudła wagonu „150A" następne problemy dynamiczne pojawiają się w konstrukcji pudła, które trzeba zaprojektować tak, aby uniknąc przenoszenia drgań w układzie wózeknadwozie [4]. Problem ten jest mniej istotny dla prędkości mniejszych od $200 \mathrm{~km} / \mathrm{h}$. Istotnym zagadnieniem, które pojawiło się przy rozwiązywaniu zagadnień dynamicznych jest ekwiwalentna stożkowatość, wynikająca ze współpracy koło-szyna. Zależność dopuszczalnej prędkości jazdy od ekwiwalentnej stożkowatości jest podana w karcie UIC 518 [7] oraz PNEN 14363:2005 [16]. Z przeprowadzonych prac studialnych wynika, że dla pojazdów poruszających się z wysokimi prędkościami wartość ta musi być bardzo mała, a jej przekroczenie powoduje znaczne pogorszenie własności dynamicznych. Konstrukcja nowego układu biegowego jest zdeterminowana również przez układ hamulcowy, który musi zapewnić odpowiednie parametry hamowania (droga hamowania, temperatura w układzie tarcza hamulcowa-okładzina cierna). Jako bazę projektową do przyszłego wózka, przystosowanego do wysokich prędkości w zakresie $250 \div 300 \mathrm{~km} / \mathrm{h}$ o nazwie $11 \mathrm{ANc}$ przyjęto wózek $11 \mathrm{ANa}$, który był przystosowany do maksymalnej prędkości $200 \mathrm{~km} / \mathrm{h}$ i zastosowany $\mathrm{w}$ prototypowym przedziałowym wagonie osobowym, typu „150A” przeznaczonym do krajowego ruchu dalekobieżnego. Przyjęcie takiej koncepcji pozwoliło na wykorzystanie doświadczeń $\mathrm{z}$ badań prototypu wózka $11 \mathrm{ANa}$, zwłaszcza z badań statycznych i zmęczeniowych ramy wózka, wykonanych w IPS „Tabor” Poznań oraz badań dynamicznych przeprowadzonych na liniach krajowych przez Centrum Naukowo-Techniczne Kolejnictwa w Warszawie. Przyjęcie takiej koncepcji realizacji prac projektowobadawczych pozwoliło na wykorzystanie pudła wagonu „150A” o bazie (rozstawie czopów skrętu) równej $19 \mathrm{~m}$, dostosowanie jej do zabudowy pod wózkiem "11ANc" oraz odpowiednie zabezpieczenie konstrukcji przed drganiami strukturalnymi, przez odpowiednie usztywnienie nadwozia.

\section{Konstrukcja wózka 11ANc}

Konstrukcję wózka $11 \mathrm{ANc}$, przeznaczonego do wagonu osobowego, przystosowanego do wysokich prędkości $250 \mathrm{~km} / \mathrm{h}$ oparto o doświadczenia badawcze zebrane dla wózka $11 \mathrm{ANa} \mathrm{z}$ uwzględnieniem przepisów międzynarodowych zawartych w kartach UIC, PN-EN oraz przepisach RIC [18]. Przyjęcie takiego założenia pozwoli w przyszłości na dostosowanie takiego wózka do wymagań różnych wagonów osobowych, przeprowadzając nieznaczne modyfikacje konstrukcyjne. Widok wózka $11 \mathrm{ANc}$ z bocznej strony oraz $\mathrm{z}$ góry $\mathrm{z}$ podziałem na grupy konstrukcyjne przedstawiono na rys.1. 

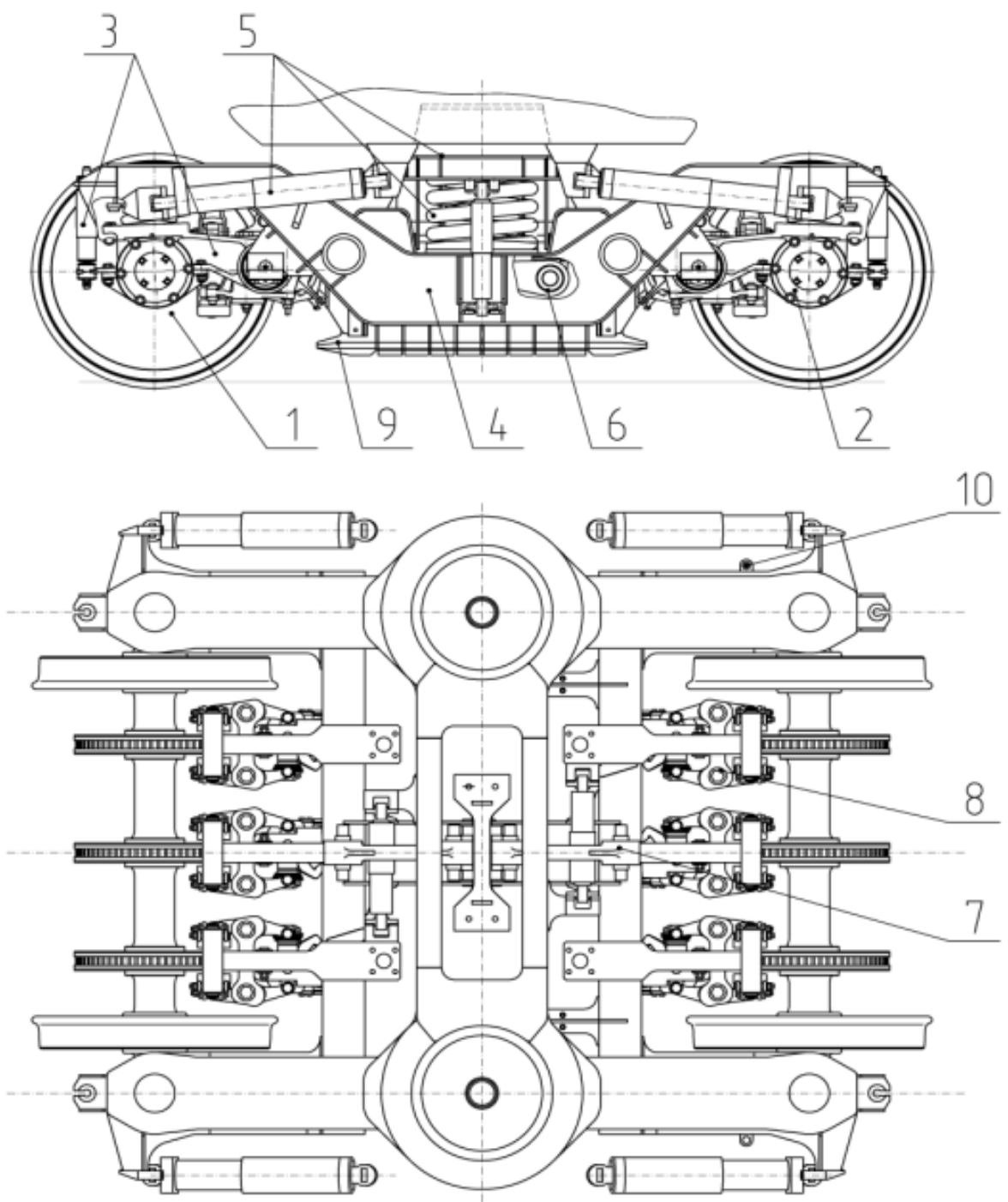

Rys.1. Wózek 11ANc przystosowany do wysokich prędkości (widok z boku i z góry) Oznaczenia użyte na rys.1:

1- zestaw kołowy z maźnicami i z trzema tarczami hamulcowymi

2- maźnice

3- układ usprężynowania pierwszego stopnia i prowadzenie maźnicy

4- rama wózka

5- belka nadwózkowa, usprężynowanie drugiego stopnia, tłumiki wężykowania

6- fragment stabilizatora przechylania

7- urządzenie pociagowe

8- mechanizm zaciskowy hamulca tarczowego

9- elektromagnetyczny hamulec szynowy

10- ogranicznik przesuwu i skrętu wózka.

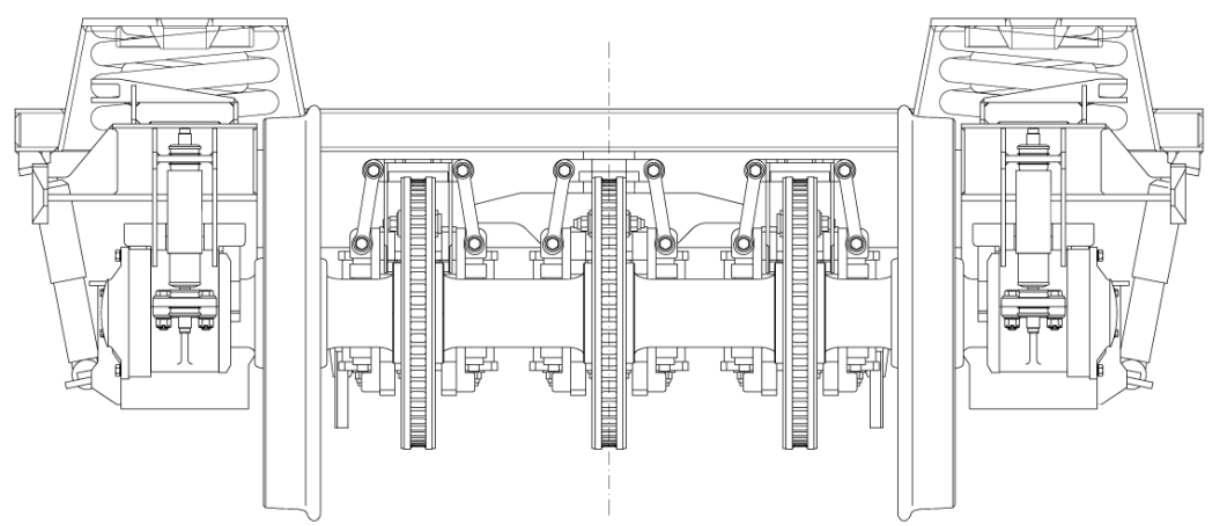

Rys.2. Wózek 11ANc przystosowany do wysokich prędkości (widok od strony czołowej) 


\section{Kompletny zestaw kołowy składa się:}

$>\mathrm{z}$ osi z czopem o wymiarach $130 \times 191 \mathrm{~mm}$ (średnica $\times$ długość) kategorii 1 , wykonanej ze stali $w$ stanie normalizowanym EA1T o parametrach wytrzymałościowych $\mathrm{R}_{\mathrm{eH}} ? 320$ MPa oraz $R_{m}=550 \div 650 \mathrm{MPa}$ i $\mathrm{A}_{5} \geq 22 \%$ wg normy PN-EN 13261: 2004 [12]; oś posiada powłokę antykorozyjną zabezpieczającą przed korozją atmosferyczną oraz przed uderzeniami mechanicznymi; powłoka antykorozyjna w skuteczny sposób zabezpiecza własności zmęczeniowe osi $\mathrm{w}$ trakcie eksploatacji;

> z kół monoblokowych kategorii 1 o średnicy tocznej $920 \mathrm{~mm}$ wtłaczanych na oś zestawu kołowego o średnicy podpiaścia $185 \mathrm{~mm}$, wykonanych ze stali ER7 z wieńcem ulepszanym cieplnie o twardości 245HB wg normy PN-EN 13262:2007 [13]; stal ER7 posiada następujące parametry wytrzymałościowe dla wieńca $\mathrm{R}_{\mathrm{eH}} \geq 520 \mathrm{MPa}, \mathrm{R}_{\mathrm{m}}=820 \div 940 \mathrm{MPa}$, $\mathrm{A}_{5} \geq 14 \%$; koła posiadają zarys zewnętrzny wieńca UIC-ORE S1002 wg karty UIC 510-2 [6], równoważny $\mathrm{z}$ zarysem $\mathrm{S} 1002$ $/ \mathrm{h} 28 / \mathrm{e} 32,5 / 15 \%$ wg normy PN-EN 13715 [14];

$>\mathrm{z}$ trzech tarcz staliwnych, wentylowanych o wymiarach $640 \times 350 \times 80 \mathrm{~mm}$ (średnica zewnętrzna×średnica wewnętrzna $\times$ szerokość wieńca); tarcze hamulcowe są wtłaczane na oś w specjalnych miejscach do tego przeznaczonych, zwanych osadzeniami lub podpiaściami; tarcze hamulcowe współpracują podczas hamowania z okładzinami ciernymi, wykonanymi ze spieku ceramicznego; przyjęcie koncepcji wózka, wyposażonego w trzy tarcze hamulcowe pozwoliło na osiagnnięcia zakładanych parametrów hamowania wagonu oraz akceptowalne temperatury na powierzchni „pierścienia ciernego" tarczy hamulcowej (ang. „friction ring surface”, niem. „Reibringfläche”) $\mathrm{T}_{1}=458,8{ }^{\circ} \mathrm{C}$ przy hamowaniu z prędkości początkowej $250 \mathrm{~km} / \mathrm{h}$ i $\mathrm{T}_{1}=607,8^{\circ} \mathrm{C}$ przy hamowaniu $\mathrm{z}$ prędkości poczatkowej $300 \mathrm{~km} / \mathrm{h}$ oraz temperatury na żebrach chłodzących tarczy hamulcowej (ang.,,cooling fins", niem.,, Kühlrippen”) $\mathrm{T}_{2}=427,2{ }^{\circ} \mathrm{C}$ przy hamowaniu $\mathrm{z}$ prędkości początkowej $250 \mathrm{~km} / \mathrm{h} \mathrm{i} \mathrm{T}_{2}=572^{\circ} \mathrm{C}$ przy hamowaniu z prędkości początkowej $300 \mathrm{~km} / \mathrm{h}$; hamulec tarczowy $\mathrm{z}$ trzema tarczami hamulcowymi posiada promień hamujący $\mathrm{r}_{\mathrm{h}}=0,23$ $\mathrm{m}$; przyjęcie koncepcji trzech tarcz hamulcowych, mimo że dwie mogłyby okazać się wystarczające pod względem energetycznym daje istotne korzyści:

- niższa temperatura pracy

- większa żywotność tarcz hamulcowych
- mniejsze zużycie okładzin ciernych, a co za tym idzie dłuższy cykl ich wymiany

- mniejszy ubytek skuteczności hamowania $\mathrm{w}$ razie awarii któregoś $\mathrm{z}$ cylindrów hamulcowych

- niższe koszty eksploatacyjne.

Wadą takiego rozwiązania jest wyższa masa wózka (zwłaszcza nieusprężynowana) oraz wyższa jego cena. Zdecydowanie większy jest jednak bilans korzyści. Wszystkie obecnie produkowane wózki do wagonów osobowych w Europie, przystosowane do prędkości 200 $\mathrm{km} / \mathrm{h}$ oraz do zakresu prędkości $250 \div 300$ $\mathrm{km} / \mathrm{h}$ posiadają trzy tarcze hamulcowe.

$>$ odlewanego korpusu maźnicy ze staliwa 340550W wg PN-ISO 3755:1994 [17] z zabudowanym stożkowym łożyskiem kompaktowym TBU (ang.,,Taper Bearing Unit") o wymiarach $130 \times 230 \times 160 \mathrm{~mm}$ ( średnica wewnętrzna×średnica zewnętrzna×szerokość łożyska) firmy SKF, o minimalnych wzdłużnych luzach montażowych wynoszących $0,1 \div 0,4 \mathrm{~mm}$ i posiadającym własne uszczelnienie (rys.3);

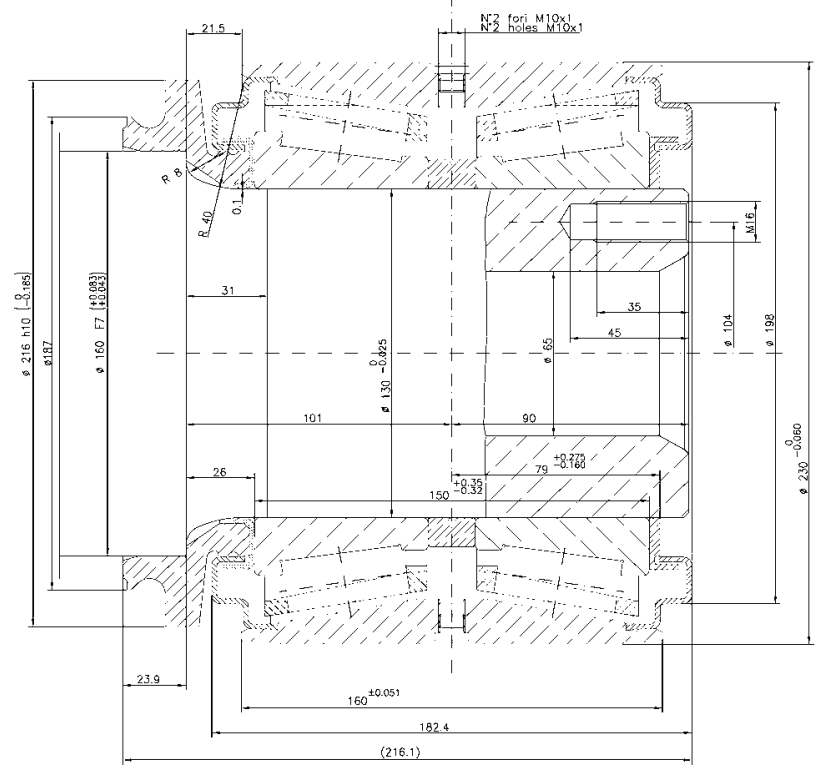

Rys.3. Łożysko bezobsługowe typu TBU $130 \times 240 \times 160$ z własnym uszczelnieniem

staliwo 340-550W posiada następujące parametry wytrzymałościowe: $\mathrm{R}_{\mathrm{e}}=340 \mathrm{MPa}$ oraz $\mathrm{R}_{\mathrm{m}}=550 \div 700 \mathrm{MPa}$ oraz $\mathrm{A}_{\min }=15 \%, \mathrm{Z}_{\text {min }}=21 \%$ oraz $\mathrm{KV}_{\min }=20 \mathrm{~J}$;

korpus maźnicy jest przystosowany do :

- osadzenia jednoramiennego wahacza umożliwiającego prowadzenie zestawu kołowego względem ramy wózka, posadowienia sprężyn zawieszenia pierwszego stopnia oraz zamocowania amortyzatora hydraulicznego 
- zabudowy pokrywy z nadajnikiem impulsów układu przeciwpoślizgowego typu REXROTH

- zabudowy pokrywy z urządzeniem uziemiającym typu FROST

- zabudowy zwykłej pokrywy zaślepiającej maźnicę.

Kompletny zestaw kołowy stanowi masę nieusprężynowaną wózka $11 \mathrm{ANc}$.

Układ usprężynowania pierwszego stopnia składa się z zespołu sprężyn śrubowych w konfiguracji równoległej ( sprężyna zewnętrzna+ sprężyna wewnętrzna) opartych dolną podstawą na maźnicach, natomiast górna podstawa znajduje się w gnieździe ramy wózka; w skład tego podzespołu wchodzą również thumiki pierwszego stopnia firmy „Sach" oraz wahacz zawieszenia pierwszego stopnia służący do prowadzenia zestawu kołowego i wyposażony w łącznik gumowometalowy (przegub wahacza) o sześciu stopniach swobody i odpowiednio dobranych sztywnościach w kierunku promieniowym oraz poosiowym; usprężynowanie pierwszego stopnia rozgranicza masy usprężynowane wózka od mas nieusprężynowanych;

Układ usprężynowania drugiego stopnia składa się $\mathrm{z}$ zespołu wielkogabarytowych sprężyn śrubowych (zwanych także sprężynami typu „flexicoil”), które jednocześnie pełnią funkcję usprężynowania pionowego i poziomego oraz układu skrętowego wózka; sprężyny są zbudowane $\mathrm{w}$ sposób zorientowany $\mathrm{w}$ celu wzajemnego zredukowania sił powodujących odchylenie podstaw; w kierunku poziomopoprzecznym układ sprężyn współpracuje z odbijakami gumowymi, uzupełniający ewentualny deficyt siły nawrotnej w przypadku wystapienia dużych przyspieszeń poprzecznych; sprężyny są także wspomagane przez stabilizator przechylania nadwozia, które wyrównuje deficyt sztywności kątowej układu zawieszenia potrzebnej do utrzymania się $\mathrm{w}$ obszarze dopuszczalnego współczynnika pochylania nadwozia; nadwozie opiera się na sprężynach za pomocą belki nadwózkowej; tłumienie drgań w zawieszeniu drugiego stopnia odbywa się za pomocą dwóch amortyzatorów pionowych oraz dwóch amortyzatorów poprzecznych.

Regulację usprężynowania przeprowadza się za pomocą podkładek, umieszczanych zarówno w usprężynowaniu pierwszego i drugiego stopnia.

Regulacja usprężynowania ma na celu:

- właściwe skonfigurowanie pionowe elementów wózka dla zapewnienia prawidłowego funkcjonowania pojazdu

- skompensowanie wichrowatości własnej wózka a także pudła dla zapewnienia korzystnego rozkładu nacisków przypadających na poszczególne koła.

W zawieszeniu pierwszego stopnia podkładka regulacyjna będzie umieszczana bezpośrednio nad zespołem sprężyn, natomiast $\mathrm{w}$ zawieszeniu drugiego stopnia podkładka regulacyjna będzie umieszczana w obszarze oparcia pudła na belce nadwózkowej.

Rama wózka jest konstrukcją spawaną, składającą się z dwóch ostojnic o zamkniętej konstrukcji skrzynkowej, połączonych dwoma rurami do mocowania mechanizmów zaciskowych hamulca tarczowego. Rury są połączone wzdłużną belką centralną do przeniesienia siły pociagowej wózek-pudło oraz nowego rozwiązania konstrukcyjnego blokady zawieszenia drugiego stopnia. Na ramę wózka użyto półwyrobów ze stali S355 wg PN-EN 100025-2:2007 [10], posiadającej granice plastyczności $\mathrm{R}_{\mathrm{e}}=355 \mathrm{MPa}$ oraz doraźną granicę na rozciaganie $R_{m}=520 \mathrm{MPa}$. Rama wózka jest przestawiona na rys.4.

Konstrukcja ramy wózka jest przystosowana do przenoszenia wszystkich sił pojawiających się w eksploatacji tzn. sił pionowych, sił poprzecznych, sił wichrowatości toru, sił hamulcowych i pochodzących od nabiegania, zdefiniowanych w PN-EN 13749: 2005 [15], które pojawiają się jako statyczne siły nadzwyczajne oraz obciążenia cykliczne, wywołujące stopniowe zmęczenie struktury nośnej, które nie powinno prowadzić do pęknięć lub uszkodzeń struktury nośnej w zakładanym okresie użytkowania wagonu osobowego. Dla ustabilizowania wymiarów wózka po spawaniu przewidziano usunięcie głównych naprężeń spawalniczych poprzez poddanie działania odpowiedniego obciążenia stabilizującego lub poprzez odprężanie wibracyjne.

Mechanizmy zaciskowe hamulca tarczowego- po 6 sztuk na wózek, wyposażone są w cylindry $\mathrm{z}$ automatycznym nastawiaczem skoku tłoka oraz $\mathrm{w}$ okładziny cierne ze spieku ceramicznego; cylindry hamulcowe zasilane będą $\mathrm{z}$ dwuobwodowej instalacji rurowej, umożliwiającej dostarczanie powietrza w sposób niezależny dla grup cylindrów przypadających na poszczególne zestawy kołowe; wózek z hamulcem ręcznym posiada dwa ( spośród sześciu) cylindry specjalne, wyposażone $\mathrm{w}$ dodatkowy zestaw dźwigniowy współpracujący $\mathrm{z}$ tłokiem cylindrowym i przystosowany do połączenia $z$ linkami cięgłowymi doprowadzonymi $\mathrm{z}$ nadwozia; wózek $\mathrm{z}$ hamulcem ręcznym posiada oznaczenie $11 \mathrm{ANc} / 1$.

Układ przenoszenia siły pociągowej-składa się $z$ dwóch układów, przy czym układ pierwszy składa się z pary współosiowych płaskich drążków przegubowych, złącznych ze sobą za pomocą specjalnego jarzma; przegubowe gumowo-metalowe końcówki drążków są zamocowane we wspornikach znajdujących się na poprzecznicach rurowych ramy wózka, natomiast jarzmo mocowane jest do wspornika pociagowego znajdującego się na belce skrętowej ostoi pudła, obejmującego podłużnicę centralną ramy wózka; jarzmo po zamocowaniu będzie stanowiło zworę tego wspornika, przechodzącą pod wspomnianą podłużnicą cen- 


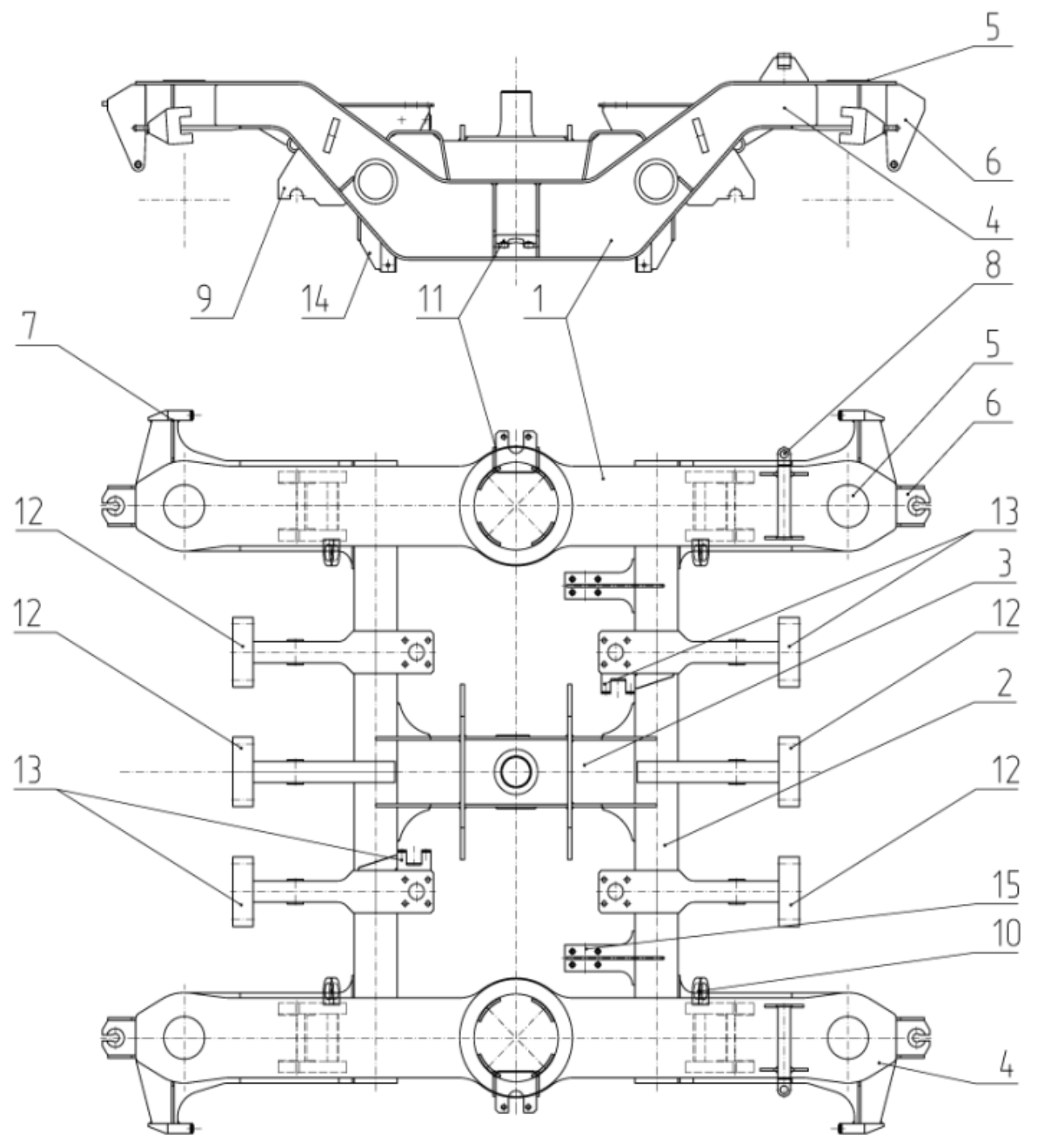

tralną ,stając się przy okazji blokadą wiążącą wózek z pudłem, wykorzystywaną między innymi podczas podnoszenia wagonu; dzięki odpowiednio dobranej sztywności układ drążków będzie przenosił siły pociagowe w zakresie normalnych oddziaływań, bez wywierania istotnego wpływu na charakterystykę ugięcia zawieszenia drugiego stopnia; układ drugi uzupełnia działanie układu pierwszego i stanowi zespół odbijaków blokujących przemieszczenia wózka względem pudła pod wpływem znacznych przeciążeń wzdłużnych. Rolę takich odbijaków spełnia cylindryczny czop przyspawany do ramy wózka w jednym centralnym punkcie, zajmujący pozycję wewnątrz owalnego otworu specjalnej płyty nośnej wspornika pociaggowego, znajdującego się na pudle. Luzy pomiędzy czopem a krawędzią otworu, rzędu $\pm 10 \mathrm{~mm}$ w kierunku wzdłużnym oraz $\pm 60 \mathrm{~mm} \mathrm{w}$ kierunku poprzecznym, pozwolą na przejmowanie przez te elementy nadwyżki siłowej w przypadku zadziałania nadzwyczajnej siły wzdłużnej (przypadek przeciążenia $5 \mathrm{~g}$ ) przy zachowaniu bezkolizyjności $\mathrm{w}$ kierunku poprzecznym, w całym zakresie gry poprzecznej zawieszenia drugiego stopnia.

Rys.4. Rama wózka 11ANc

Oznaczenia na rys.4.:

1- ostojnica

2- poprzecznica

3- podłużnica

4- gniazda sprężyn

5- płyty bazowe służące do podpory ramy podczas obróbki mechanicznej

6- wspornik amortyzatora usprężynowania pierwszego stopnia

7- wspornik amortyzatora wężykowania

8- wspornik ogranicznika przesuwu

9- wspornik do mocowania wahaczy maźniczych

10- wsporniki transportowe na ściankach bocznych

11- wspornik amortyzatora pionowego

12- wspornik przeznaczone do zawieszenia hamulca tarczowego i szynowego

13- wspornik do zamocowania amortyzatora poziomopoprzecznego i do zawieszenia hamulca tarczowego i szynowego

14- wspornik do zamocowania prowadzenia płóz elektromagnetycznych

15- wspornik do zamocowania podpór stabilizatora przechylania. 
Szynowy hamulec elektromagnetyczny( adoptowany $z$ wózka 11ANa)- produkcji BSI posiada następującą budowę:

$\Rightarrow$ zestaw hamujący stanowią dwie płozy hamulcowe, obie wyposażone w zestaw elektromagnesów o długości $1000 \mathrm{~mm}$, połączone wzajemnie za pomocą dwóch łączników rurowych

$\Rightarrow$ zestaw hamujący zawieszony na ramie wózka za pośrednictwem czterech cylindrów pneumatycznych

$\Rightarrow$ zestaw hamujący w pozycji zluzowanej (cylindry opróżnione) prowadzony jest $\mathrm{w}$ ramie wózka za pomocą czterech centrowników stożkowych gumowo-metalowych

$\Rightarrow$ zestaw hamujący w pozycji hamowanej ( cylindry napełnione powietrzem) przekazuje silę hamowania w ramę wózka poprzez cztery prowadnice pionowe. Hamulec szynowy jest przedstawiony na rys.5.

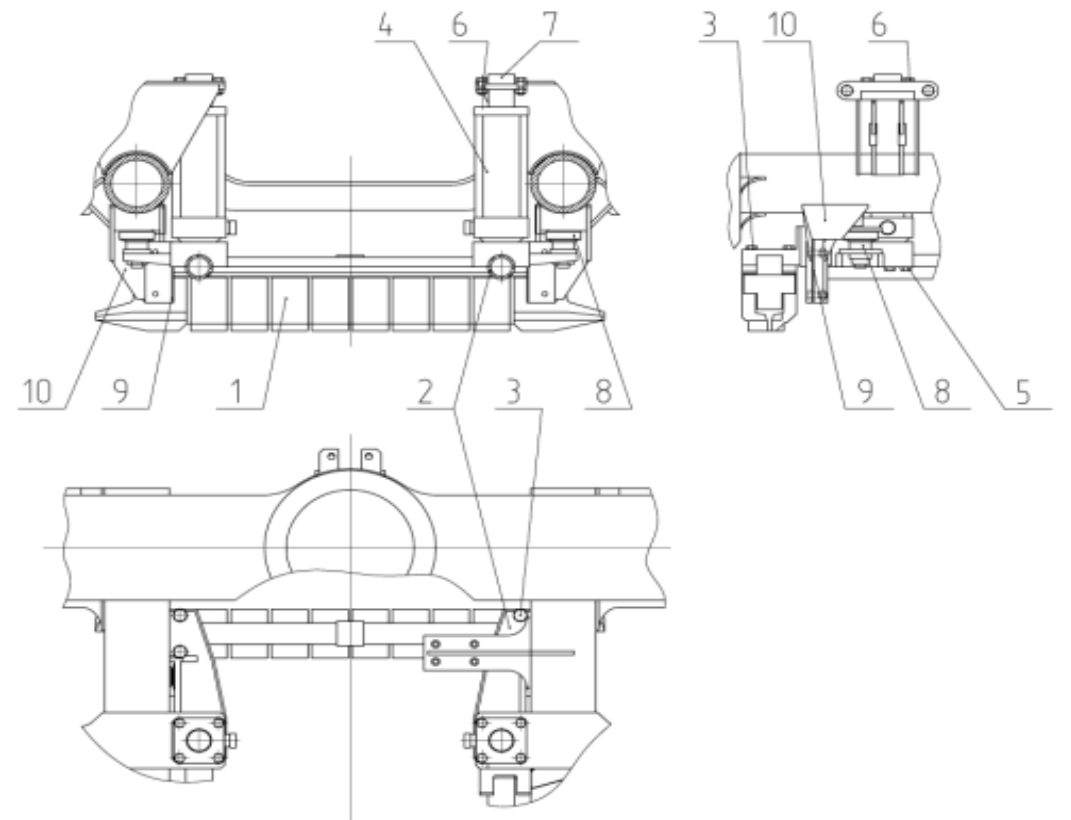

Rys.5. Szynowy hamulec elektromagnetyczny

Oznaczenia użyte na rys. 5:

1-wielosegmentowe płozy elektromagnetyczne

2-poprzeczne łączniki rurowe, łączące płozy elektromagnetyczne

3-łapy do przykręcania śrub

4-cylindry skokowe

5-śruby mocujące cylindry skokowe od dołu

6-śruby mocujące cylindry skokowe od góry

7-wlot sprężonego powietrza zasilającego cylinder pionowo od góry

8-centrowniki stożkowe utwierdzające zestaw płóz w sposób sprężysty i bezluzowy

9-zaciski przewodów zasilających

10-okładziny ochronne.

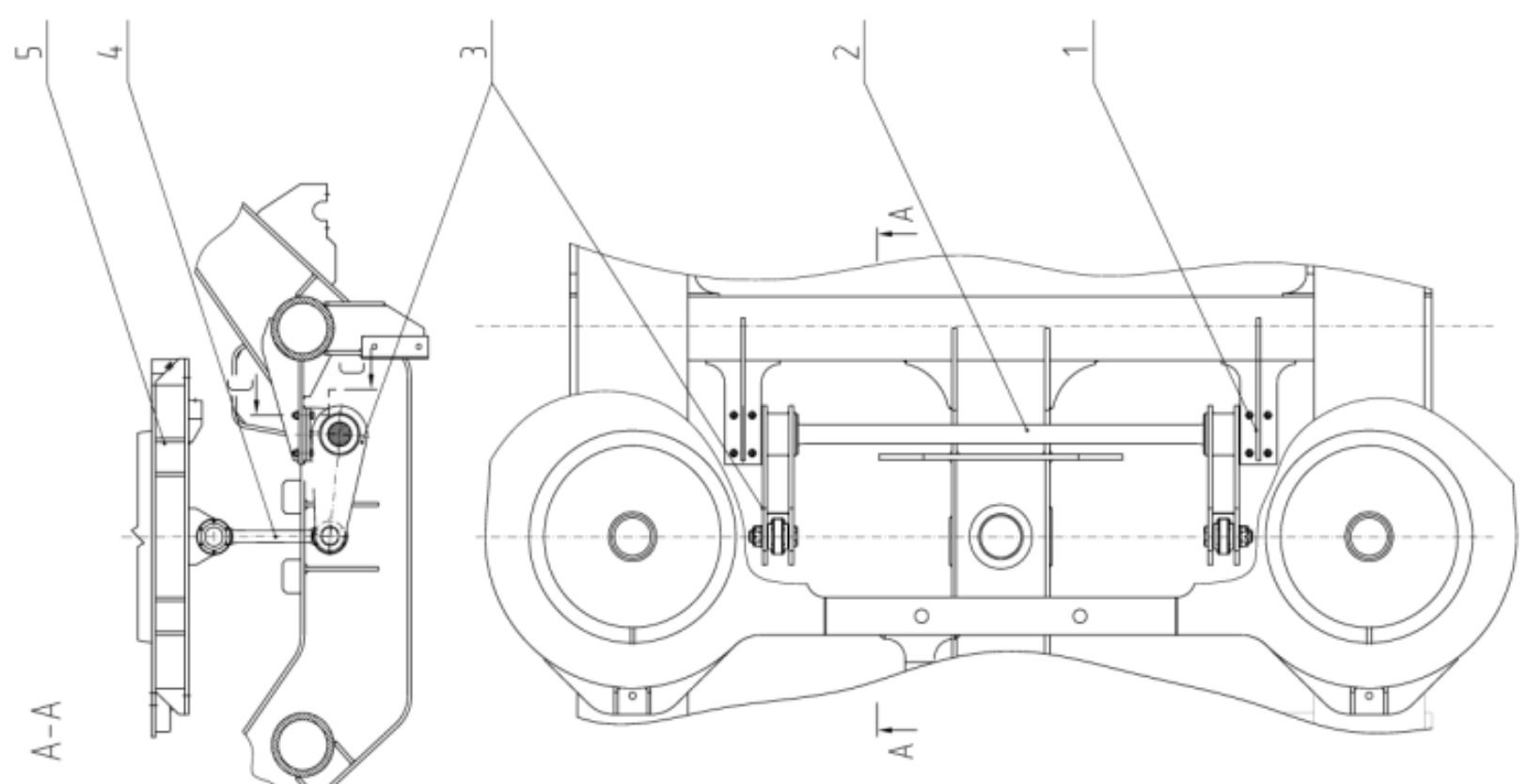

Oznaczenia na rys.6:

1-wspornik ramy wózka

Rys.6. Stabilizator przechylania nadwozia wózka 11ANc

2-drążek skrętny

3-dźwignie

4-łącznik

5-belka nadwózkowa 
Stabilizator przechylania poprzecznego nadwozia zadaniem stabilizatora przechylania jest zwiększenie sztywności zawieszenia drugiego stopnia na przechył poprzeczny pudła $\mathrm{w}$ takim stopniu, aby współczynnik pochylania ,„" nadwozia przy pełnym obciążeniu nadwozia był mniejszy lub równy 0,4 ; niedotrzymanie powyższego warunku oznacza konieczność skonstruowania nietypowego pudła, niezgodnego $\mathrm{z}$ wymaganiami karty UIC 567-2 [8]; jak wynika z obecnej praktyki konstrukcyjnej najniższa częstotliwość drgań własnych w kierunku pionowym przy pełnej ładowności wynosi ok.1 Hz, przy rozstawie poprzecznym sprężyn wynoszącym $2 \mathrm{~m}$, realizuje współczynnik pochylania mieszczący się $\mathrm{w}$ przedziale $0,5 \div 0,6$; w takim przypadku stosowanie stabilizatora przechylania jest konieczne.

Stabilizator przechylania poprzecznego jest zaprojektowany tak, aby uzyskać współczynnik pochylania nadwozia, które spełnia następujące warunki:

- $s \leq 0,4$ dla wagonu osobowego o masie brutto

- $s \geq 0,25$ dla wagonu osobowego o masie w stanie próżnym.

Brak stabilizatora przechylania poprzecznego powoduje, że współczynnik pochylania osiaga wartości w zakresie $0,33 \div 0,70 \mathrm{w}$ zależności od masy wagonu, wobec wartości dopuszczalnej wynoszącej

$s \leq 0$,4. Przy założonych parametrach konstrukcyjnych stabilizatora przechylania współczynnik pochylania osiaga wartości w zakresie $0,18 \div 0,38 \mathrm{w}$ zależności od masy wagonu. Stabilizator przechylania nadwozia jest pokazany na rys.6.

Amortyzatory hydrauliczne- w wyniku przeprowadzonych analiz konstrukcyjnych okazało się, że warunki zabudowy amortyzatorów na wózku typu $11 \mathrm{ANc}$ wymuszają przyjęcie produktów firmy SACHS, która oferuje wyroby bardziej kompaktowe (średnica, długość minimalna przy takim samym sko$\mathrm{ku}$ ); dotyczy to szczególnie amortyzatorów dla zawieszenia drugiego stopnia, dla zabudowy których jest niezwykle mało wolnej przestrzeni; zestawienie amortyzatorów podano w tabeli 1.
Amortyzatory thumienia drgań są wyposażone w przeguby gumowe $\mathrm{z}$ zawulkanizowanym sworzniem, który przykręca się do wsporników na wózku, co przyczynia się do łatwego montażu. Cechą charakterystyczną amortyzatorów jest kontrola sił generowanych przy wysoko tłumionych prędkościach za pomocą specjalnych zaworów odcinających. Amortyzatory wężykowania wózka odróżniają się od pozostałych amortyzatorów ( poza długością i skokiem) znaczną sztywnością promieniową przegubów oraz zdecydowanie większą siłą tłumienia.

Ograniczniki przesuwu poprzecznego i skrętu limituje grę poprzeczną nadwozia w następujący sposób:

- podczas jazdy na torze prostym gra poprzeczna jest określona przez poprzeczne odbijaki gumowometalowe, zabudowane w liczbie 2 sztuk na każdym wsporniku pociagowym pudła ( łącznie 4 sztuki na wagon), które wchodzą do współpracy z płytami oporowymi, znajdującymi się na belce podłużnej ramy wózka

- podczas jazdy w huku torowym gra poprzeczna jest limitowana w kierunku do środka krzywizny łuku za pomocą czterech zespołów mechanizmu krzywkowego ( po 2 sztuki na każdy wózek), natomiast $\mathrm{w}$ kierunku na zewnątrz krzywizny łuku toru jest ona limitowana przez wyżej wymienione odbijaki

- każdy z czterech mechanizmów krzywkowych składa się z krzywki wspawanej w ostoję nadwozia oraz rolki łożyskowanej we wsporniku ramy wózka

- geometria krzywki jest ustalona w taki sposób, aby luz między powierzchnią roboczą a rolką ograniczał ruch poprzeczny nadwozia tylko w kierunku do środka krzywizny łuku toru, przy czym ograniczenie to jest zmienne w funkcji promienia łuku i spełnia wymagania karty UIC 567-2 [8].

Zestawienie amortyzatorów zastosowanych w wózku 11 ANc

Tabela 1

\begin{tabular}{|c|c|c|c|c|}
\hline $\begin{array}{c}\text { Typ amortyzatora } \\
\text { SACHS }\end{array}$ & Zastosowanie & $\begin{array}{c}\text { Ilość sztuk na wó- } \\
\text { zek }\end{array}$ & $\begin{array}{c}\text { Zakres wartości } \\
\text { wspólczynnika } \\
\text { tłumienia }\end{array}$ & $\begin{array}{c}\text { Sztywność przegu- } \\
\text { bu amortyzatora }\end{array}$ \\
\hline- & - & - & Ns/m & N/m \\
\hline $\begin{array}{c}\text { T50/20 pionowy } \\
\text { wariant A }\end{array}$ & $\begin{array}{c}\text { Tłumienie drgań } \\
\text { zawieszenia pierw- } \\
\text { szego stopnia }\end{array}$ & 4 & $0 \ldots .20000$ & 4500000 \\
\hline $\begin{array}{c}\text { T50/20 pionowy } \\
\text { wariant } \mathrm{D}^{1)}\end{array}$ & $\begin{array}{c}\text { Tłumienie drgań } \\
\text { zawieszenia drugie- } \\
\text { go stopnia }\end{array}$ & 2 & $0 \ldots 100000$ & 20000000 \\
\hline $\begin{array}{c}\text { T50/20 poziomy } \\
\text { wariant } \mathrm{D}^{1)}\end{array}$ & $\begin{array}{c}\text { Tłumienie drgań } \\
\text { zawieszenia drugie- } \\
\text { go stopnia }\end{array}$ & 2 & $0 \ldots 100000$ & 20000000 \\
\hline $\begin{array}{c}\text { T70/28 poziomy } \\
\text { wariant } \mathrm{L}^{1)}\end{array}$ & $\begin{array}{c}\text { Tłumienie wężyko- } \\
\text { wania }\end{array}$ & 4 & $0 \ldots .2000000$ & 70000000 \\
\hline
\end{tabular}

wariant dotyczy wykonania mocowania thumika 


\section{Parametry konstrukcyjne wózka}

Wózek 11ANc posiada następujące parametry użytkowo-eksploatacyjne:

$\Rightarrow$ parametry wymiarowe:

++ prześwit toru (wymiar nominalny)-1435 $\mathrm{mm}$

++ maksymalna szerokość wózka- $2830 \mathrm{~mm}$

++ długość wózka-3576 mm

++ baza wózka (rozstaw osi zestawów kołowych)-2,6 m ( wydłużona o $0,1 \mathrm{~m}$ w stosunku do wózka 11ANa posiadającego bazę 2,5 $\mathrm{m})$

++ rozstaw zespołów sprężyn zawieszenia pierwszego stopnia-2 $\mathrm{m}$

++ rozstaw środków maźnic $\mathrm{w}$ zestawie kołowym-2 m

++ rozstaw płaszczyzn kręgów tocznych kół zestawu kołowego- $1,5 \mathrm{~m}$

++ rozstaw zespołów sprężyn zawieszenia drugiego stopnia- $2 \mathrm{~m}$

++ rozstaw środków skrajnych tarcz hamulcowych na osi $-0,900 \mathrm{~m}$

++ rozstaw osi amortyzatorów wężykowania wózka-2,682 m

++ średnica toczna koła monoblokowego: w stanie nowym- $0,920 \mathrm{~m}$

po ostatniej reprofilacji- 0,870

całkowicie zużytego- $0,860 \mathrm{~m}$

++ odległość pomiędzy osią maźnicy a osią przegubu wahacza- $0,44 \mathrm{~m}$

++ odległość pomiędzy osią maźnicy a osią amortyzatora pierwszego stopnia$0,27 \mathrm{~m}$

++odległość tarczy hamulcowej od dolnego zarysu skrajni kinematycznej w stanie nowym-40 mm

++odległość tarczy hamulcowej od dolnego zarysu skrajni kinematycznej przy całkowicie zużytym wieńcu koła-10 mm

$\Rightarrow$ masy wózka:

++ nieusprężynowana masa wózka-3410 kg (44\% łącznej masy)

++ usprężynowana masa wózka przez zawieszenie pierwszego stopnia- $3353 \mathrm{~kg}(43,5 \%$ łącznej masy wózka)

++ usprężynowana masa wózka przez zawieszenie drugiego stopnia-937 kg (12,1 \% łącznej masy wózka)

++ całkowita masa wózka-7700 kg

$\Rightarrow \quad$ sztywność pionowa zawieszenia wózka:

$+\quad 775 \div 840 \mathrm{kN} / \mathrm{m}$

$\Rightarrow$ nośność wózka:

++ maksymalny nacisk zestawu kołowego na tor w stanie statycznym-156,95 kN

++ obciążenie eksploatacyjne przypadające na wózek-205 kN)
++ obciążenia nadzwyczajne przypadające na wózek-225 kN ${ }^{*}$

*) obciążenie przypadające na obydwie ostojnice wózka i wywierane przez komplet usprężynowania drugiego stopnia

$\Rightarrow$ teoretyczna prędkość jazdy ze względu na ryzyko wystapienia drgań niestatecznych:

++ nominalna $-250 \mathrm{~km} / \mathrm{h}$

++ dopuszczalna $-280 \mathrm{~km} / \mathrm{h}$

++ krytyczna-310 km/h

$\Rightarrow$ parametry kinematyki wózka:

\# graniczne przemieszczenie poprzeczne nadwozia względem wózka:

++ na prostym odcinku toru- $\pm 0,06 \mathrm{~m}$

++ na tuku torowym $\mathrm{R}=250 \mathrm{~m}$ w kierunku odśrodkowym- $0,05 \mathrm{~m}$

++ na tuku torowym $\mathrm{R}=250 \mathrm{~m}$ w kierunku dośrodkowym- $0,022 \mathrm{~m}$

++ na łuku torowym $\mathrm{R}=150 \mathrm{~m}$ (najmniejszy promień łuku szlakowego) w kierunku odśrodkowym- $0,05 \mathrm{~m}$ )

++ na tuku torowym $\mathrm{R}=150 \mathrm{~m}$ w kierunku dośrodkowym-0,0195 m

\# nominalny kąt skrętu wózka względem nadwozia:

++ na łuku torowym $\mathrm{R}=250 \mathrm{~m}-2,177 ?(0,038$ rad)

++ na łuku torowym $\mathrm{R}=150 \mathrm{~m}-3,628$ ? ( $0,06333 \mathrm{rad})$

++ na łuku torowym $\mathrm{R}=80 \mathrm{~m}$ (najmniejszy promień łuku fabrycznego) $-6,803^{\circ}$ $(0,11875 \mathrm{rad})$

\# graniczny kąt skrętu wózka względem nadwozia w położeniu narożnikowym:

++ na luku torowym $\mathrm{R}=250 \mathrm{~m}-3,495 ?(0,061$ $\mathrm{rad})$

++ na łuku torowym $\mathrm{R}=150 \mathrm{~m}-4,950 ?(0,0864$ $\mathrm{rad})$

++ na tuku torowym $\mathrm{R}=80 \mathrm{~m}-7,46 ?(0,1303$ $\mathrm{rad})$.

$\Rightarrow$ thumienie drgań:

amortyzator pionowy zawieszenia pierwszego stopnia:

++ siła tłumienia przy prędkości ruchu tłoka $0,1 \mathrm{~m} / \mathrm{s}-500 \mathrm{kN}$

++ siła tłumienia przy prędkości ruchu tłoka $0,3 \mathrm{~m} / \mathrm{s}-750 \mathrm{kN}$

++ sztywność jednego przegubu w kierunku działania siły thumienia-4 $500 \mathrm{kN} / \mathrm{m}$ amortyzator pionowy zawieszenia drugiego stopnia:

++ siła thumienia przy prędkości ruchu tłoka $0,1 \mathrm{~m} / \mathrm{s}-3000 \mathrm{kN}$ ++ siła tłumienia przy prędkości ruchu tłoka $0,3 \mathrm{~m} / \mathrm{s}-4750 \mathrm{kN}$ 
++ sztywność jednego przegubu w kierunku działania siły thumienia-20000 $\mathrm{kN} / \mathrm{m}$

amortyzator poprzeczny zawieszenia drugiego stopnia:

++ siła tłumienia przy prędkości ruchu

tłoka $0,1 \mathrm{~m} / \mathrm{s}-2500 \mathrm{kN}$

++ siła thumienia przy prędkości ruchu

tłoka $0,3 \mathrm{~m} / \mathrm{s}-3960 \mathrm{kN}$

++ sztywność jednego przegubu-20 000

$\mathrm{kN} / \mathrm{m}$

amortyzator wężykowania wózka:

++ siła thumienia przy prędkości ruchu tłoka $0,1 \mathrm{~m} / \mathrm{s}-3900 \mathrm{kN}$

++ siła tłumienia przy prędkości ruchu tloka $0,3 \mathrm{~m} / \mathrm{s}-6000 \mathrm{kN}$

++ sztywność jednego przegubu-70000 $\mathrm{kN} / \mathrm{m}$

\section{Perspektywy rozwojowe wózka 11ANc}

Podwyższenie dopuszczalnej prędkości jest związane $\mathrm{z}$ podjęciem następujących środków konstrukcyjnych:

- zwiększeniem sztywności prowadzenia maźnicy $\mathrm{w}$ kierunku wzdłużnym $\mathrm{c}_{\mathrm{x}}$ oraz poprzecznym $\mathrm{c}_{\mathrm{y}}$

- zwiększeniem efektywności tłumienia wężykowania.

Zwiększenie sztywności $\mathrm{c}_{\mathrm{x}} \mathrm{i} \mathrm{c}_{\mathrm{y}}$ jest równoznaczne ze zmianami w przegubie gumowo-metalowym wahacza, co może prowadzić do wzrostu maksymalnej siły dynamicznej oddziaływania zestawu kołowego na tor kierunku poprzecznym. Kryterium to jest przedstawione w PN-EN 14363 [16]:

$$
\begin{aligned}
& \max \sum Y=\sum \bar{Y}_{99,85 \%}+3 S_{\sum 99,85 \%}< \\
& \sum Y_{\text {max }, \lim }=10+\frac{2}{3} Q_{0}
\end{aligned}
$$

gdzie:

$\sum Y_{99,85 \%}$-wartość średnia kwantylu rzędu 99,85\% sumy sił poprzecznych Y działających na zestaw kołowy

$S_{\sum Y 99,85 \%}$-odchylenie standardowe kwantylu rzędu $99,85 \%$ sumy sił poprzecznych $\mathrm{Y}$ działających na zestaw kołowy ( wartość $\mathrm{w} \mathrm{kN}$ otrzymana $\mathrm{z}$ pomiaru) $2 Q_{0}$ - nacisk pionowy zestawu kołowego na tor ( wartość $\mathrm{w} \mathrm{kN}$ otrzymana $\mathrm{z}$ pomiaru).

Zmniejszenie masy nieuspręzynowanej jest możliwe poprzez zastosowanie:

- kół monoblokowych o mniejszych średnicach, co jest ograniczone wymogiem zachowania dolnego zarysu skrajni kinematycznej wg karty UIC 505-1 [5]

- zastosowanie korpusów maźnic i wahacza ze stopów lekkich

- zastosowanie osi drążonych, przy zagwarantowaniu własności wytrzymałościowych
- zgodnie z normą PN-EN 13103:2003 [11].

Tak więc sztywności poprzeczne $c_{x} i c_{y}$ powinny być tak dobrane tak, aby dolne granice stateczności jazdy i maksymalnej siły poprzecznej oddziaływania na tor były osiągnięte przy tej samej prędkości.

Zwiększenie sztywności tłumienia wężykowania wymaga jednoczesnego podjęcia następujących zabiegów konstrukcyjnych, prowadzących do:

- zwiększenia siły tłumienia amortyzatorów hydraulicznych, przy czym parametrem ograniczającym jest ściśliwość oleju; w związku z tym konieczne będzie zastosowanie amortyzatorów o większej średnicy tłoka albo zwiększenie ilości amortyzatorów w układzie „, wózek-pudło"

- zwiększenia sztywności promieniowej przegubów amortyzatora, zwłaszcza gdy liczba amortyzatorów pozostanie niezmieniona

- dodatkowego usztywnienia struktury nośnej zwłaszcza pudła, w taki sposób aby zminimalizować ugięcia struktury w punktach mocowania amortyzatorów oraz uniknąć sprzężenia rezonansowego drgań strukturalnych pudła $z$ wymuszeniami pochodzącymi od wężykowania nadwozia.

Zwiększenie thumienia wężykowania jest ograniczone warunkiem związanym z momentem oporowym $\mathrm{M}_{\mathrm{RZ}}$, występującym pomiędzy wózkiem a nadwoziem, przy czym moment ten powinien spełniać warunek wg PNEN 14363:2005 [16]:

$$
\frac{M_{Z R}}{2 Q_{0} \cdot 2 a^{+}} \leq 0,1
$$

gdzie:

$$
2 \mathrm{a}^{+} \text {-baza wózka. }
$$

Ze warunku, przedstawionego we wzorze (2) wynika, że thumienie wężykowania łącznie $\mathrm{z}$ reakcją sprężyn wyczerpuje ten warunek. W związku z tym zwiększając tłumienie wężykowania, należy jednocześnie zmniejszyć moment oporowy, pochodzący od sprężyn zawieszenia drugiego stopnia.

Największym problemem towarzyszącym rozwijaniu wysokich prędkości mogą okazać się drgania strukturalne pudła stalowego, które zostały szczegółowo omówione w opracowaniu [4]. Mimo że problematyka dotyczyła tylko pudła wagonu $150 \mathrm{C}$, to należy wyjść z założenia że dotyczy ona również pudeł innych typów wagonów osobowych klasy UIC-Z produkowanych wcześniej w kraju. Należy spodziewać się, że wężykowanie wózka występujące przy wysokich prędkościach jazdy może osiagnąć częstotliwości rzędu $8 \mathrm{~Hz}$, które pokrywają się z częstotliwościami własnymi drgan strukturalnych pudła, co może prowadzić do zjawiska rezonansu.

W przypadku wystąpienia rezonansu możliwe jest wystapienie następujących zagrożeń: 
- wytrzymałość zmęczeniowa pudła może okazać się niewystarczająca,

- może pojawić się dyskomfort odczuwany przez pasażerów, spowodowany nadmierną emisją hałasu, który jest emitowany przez drgające elementy stalowe pudła

- amortyzatory wężykowania wskutek wzmożonych amplitud drgań nośników związanych z pudłem mogą utracić swoją skuteczność i funkcję.

Kolejnym warunkiem ograniczającym rozwój konstrukcji jest nośność wózka oraz miękkość usprężynowania, której maksymalna wartość związana jest z warunkiem sprzęgania wagonów, zawartym w przepisach RIC [18], który wyraża się następująco:

$$
\text { gdzie: } \quad \Delta f_{I}+\Delta f_{I I}+\Delta z \leq \Delta H
$$

$\Delta \mathrm{f}_{\mathrm{I}^{-}}$przyrost ugięcia usprężynowania , stan próżnystan ładowny" wagonu

$\Delta \mathrm{f}_{\mathrm{II}^{-}}$przyrost ugięcia usprężynowania „, stan próżnystan ładowny" wagonu

$\Delta$ z- zakres zużycia koła, nie podlegający regulacji i osiadanie relaksacyjne usprężynowania

$\Delta \mathrm{H}$ - dopuszczalna różnica wysokości położenia osi zderzaków w dowolnym miejscu stadium zużycia i masy wagonu.

W przypadku gdy wózek jest wyposażony w sprężyny konwencjonalne warunek ten może ograniczać ładowność pojazdu i miękkość usprężynowania. Jeśli stosuje się kompensację zużycia, to wówczas zmniejsza się wpływ czynnika $\Delta z$ i ograniczenia te można złagodzić.

\section{Wnioski}

Wózek $11 \mathrm{ANc}$ jest konstrukcją, która została opracowana $\mathrm{w}$ oparciu o gruntowną analizę przepisów krajowych oraz międzynarodowych oraz $\mathrm{w}$ oparciu o bogate doświadczenia zdobyte podczas projektowania, wykonania wózków prototypowych 11ANa zaprojektowanego dla wagonu osobowego $150 \mathrm{~A}$, przystosowanego do prędkości $200 \mathrm{~km} / \mathrm{h}$. Wzajemne powiązanie konstrukcyjne obydwu konstrukcji wózków pozwoliło na wykorzystanie niektórych elementów jakimi są np. sprężyny zawieszenia drugiego stopnia, belka nadwózkowa ( po drobnych przeróbkach), hamulce szynowe, elementy stabilizatora pochylania, urządzenie uziemiające firmy FROST oraz elementy urządzenia przeciwpoślizgowego, które mogą być adoptowane i użyte do budowy konstrukcji prototypowych nowych wózków.

Wózek 11ANc spełnia wymagania w zakresie własności dynamicznych, wytrzymałościowych (w zakresie wytrzymałości statycznej z obciążeniami nadzwyczajnymi, występującymi w eksploatacji oraz wytrzymałości zmęczeniowej), wymaganych parametrów hamowania oraz dopuszczalnej przestrzeni pod zabudowę wynikających z konieczności nieprzekraczania zarysu odniesienia skrajni kinematycznej we wszystkich stanach eksploatacyjnych. Dużo elementów jak rama wózka, korpus maźnicy i wahacza, stabilizator przechylania nadwozia, sprężyny zawieszenia pierwszego i drugiego stopnia mogą być wykonane przez przemysł krajowy. Dotyczy to również montażu samego wózka, który może być przeprowadzony przez obecne wytwórnie wózków i układów biegowych. Konstrukcja wózka $11 \mathrm{ANc}$ jest rozwojowa i może podlegać licznym modyfikacjom $\mathrm{w}$ zależności od potrzeb klienta. Pozytywne wyniki badań zwłaszcza w zakresie dynamicznym mogą być wykorzystywanie do projektowania wózków zespołów trakcyjnych przystosowanych do wysokich prędkości, spełniających wymagania karty UIC 660 [9].

\section{Literatura}

[1] Sobaś M.: Ekwiwalentna stożkowatość styku koło-szyna i jej znaczenie we współczesnej analizie własności dynamicznych pojazdu szynowego. Pojazdy Szynowe Nr 1/2005.

[2] Sobaś M.: Rozwiqzania konstrukcyjne uktadów biegowych wagonów osobowych przystosowanych do wysokich prędkości. Pojazdy Szynowe Nr 4/2008.

[3] Sobaś M.: Tendencje rozwojowe, wytyczne dla projektowania $i$ kryteria oceny uktadów biegowych wagonów osobowych przeznaczonych do wysokich prędkości. Pojazdy Szynowe Nr $1 / 2009$.

[4] Wittenbeck L., Sobaś M.: Analiza modalna bezprzedziałowego wagonu osobowego. XVIII Konferencja Pojazdów Szynowych. Materiały konferencyjne Politechniki Ślaskiej. Katowice-Ustroń 17-19.09.2008

[5] Karta UIC 505-1: Pojazdy kolejowe. Skrajnia pojazdów. 10-te wydanie z maja 2006

[6] Karta UIC 510-2: Pojazdy doczepne. Warunki dla stosowania kót o różnych średnicach $w$ układach biegowych różnego typu. 4-te wydanie, kwiecień 2002.

[7] Karta UIC 518: Badania i homologacja pojazdów szynowych z punktu widzenia właściwości dynamicznych, bezpieczeństwa jazdy, obciqżenia toru i parametrów biegowych. 3-cie wydanie, październik 2005.

[8] Karta UIC 567-2: Zunifikowane wagony pasażerskie typu Z dopuszczone do ruchu międzynarodowego. Charakterystyki. 4-te wydanie z 1.07.1991 ze zmianq 1.07.1995

[9]Karta UIC 660: Przepisy dotyczqce zapewnienia technicznej kompatybilności dla pociagów dostosowanych do wysokich prędkości. Wydanie 2, sierpień 2002.

[10]PN-EN 10025-2:2007: Wyroby walcowane na goraco ze stali konstrukcyjnych-Część 2: Warunki techniczne dostawy stali konstrukcyjnych niestopowych.

[11] PN-EN 13103: 2003: Zestawy kołowe i wózki. Osie zestawów kołowych tocznych. Zasady konstrukcji.

[12] PN-EN 13261:2004: Kolejnictwo-Zestawy kolowe i wózkiOsie- Wymagania dotyczqce wyrobu.

[13]PN-EN 13262:2007: Kolejnictwo-Zestawy kołowe $i$ wózkiKoła-Wymagania dotyczace wyrobu.

[14] PN-EN 13715: 2006: Kolejnictwo-Zestawy kolowe i wózkiKoła-Zarys zewnętrzny koła

[15] PN-EN 13749:2005: Kolejnictwo-Zestawy kołowe $i$ wózkiMetody określania wymagań konstrukcyjnych dla ram wózków.

[16]PN-EN 14363:2005: Kolejnictwo- Badania własności dynamicznych przed dopuszczeniem pojazdów szynowych. Badania własności biegowych i próby stacjonarne.

[17] PN-ISO 3755:1994: Staliwo konstrukcyjne ogólnego przeznaczenia.

[18] Przepisy RIC: Umowa o wymianie i użytkowaniu wagonów pasażerskich $w$ komunikacji międzynarodowej. Ważna od 1 stycznia 2001. 